\title{
EFEKTIVITAS PEMBELAJARAN MATEMATIKA REALISTIK DENGAN PERMAINAN GATRIK PADA MATERI OPERASI HITUNG CAMPURAN KELAS IV SD
}

\author{
Alfatah Ibnu Alkulub \\ Mahasiswa Program Pascasarjana, Prodi Pendidikan Dasar, Universitas Negeri Surabaya, \\ e-mail: alfatahalkulub@mhs.unesa.ac.id
}

Received : Maret 2019

Reviewed : April 2019

Accepted : $\quad$ Mei 2019

Published : Mei 2019

\section{ABSTRACT}

This research has purposed to find out the effectiveness of realistic mathematics education with gatrik game on arithmatic operation mix material in elementary school grade IV at Public Elementary School Palang district Tuban. The result data analysis of implementation realistic mathematics education materials revealed to: (1) Teachers be able to teaching the materials nicely, (2) Students activities during learning process is effective, (3) Students responses during learning process are positive, and (4) classical Students completeness is achieved. Based on the result of this research, Researcher concluded that realistic mathematics learning using gatrik game is effective when applied on arithmatic operation mix in elementary school grade $I V$.

Keywords: Realistic mathematic education and gatrik games

\section{ABSTRAK}

Penelitian ini bertujuan mengetahui keefektifan pembelajaran matematika realistik dengan permainan gatrik pada materi operasi hitung campuran di Kelas IV Sekolah Dasar Negeri Palang Kabupaten Tuban. Hasil analisis data implementasi perangkat pembelajaran terungkap bahwa: (1) guru dapat melaksanakan pembelajaran dengan baik, (2) aktivitas siswa selama pembelajaran efektif, (3) respon siswa terhadap pembelajaran positif, dan (4) ketuntasan belajar siswa secara klasikal tercapai.Berdasarkan hasil penelitian tersebut, peneliti menyimpulkan bahwa pembelajaran matematika realistik dengan permainan gatrik efektif digunakan pada materi operasi hitung campuran di kelas IV SD.

Kata Kunci: pembelajaran matematika realistik dan permainan gatrik.

\section{PENDAHULUAN}

Matematika merupakan mata pelajaran yang diajarkan di sekolah dasar. Niss (dalam Hadi, 2005:3) berpendapat bahwa salah satu alasan utama diberikannya matematika kepada siswa-siswa di sekolah dasar adalah untuk memberikan kepada setiap individu pengetahuan yang dapat membantu mereka untuk mengatasi berbagai hal dalam kehidupan seperti pendidikan atau pekerjaan, kehidupan pribadi, kehidupan sosial, dan kehidupan sebagai warga negara. Oleh karena itu, matematika merupakan mata pelajaran yang penting bagi setiap peserta didik.

Mata pelajaran matematika sangat penting karena mempunyai banyak relevansi dengan aktivitas sehari-hari. Hal ini sejalan dengan pendapat Abdurahman (2003:252) yang mengatakan bahwa matematika adalah suatu cara untuk memacahkan masalah yang dihadapi manusia. Beberapa contoh pemecahan masalah dalam kehidupan sehari-hari dengan menggunakan matematika adalah transaksi jual beli, menghitung luas daerah, dan menghitung jarak yang ditempuh.

Pentingnya mata pelajaran matematika juga didukung oleh kebijakan pemerintah. Salah satu kebijakan tersebut adalah memberikan mata pelajaran matematika kepada setiap individu sejak sekolah dasar dan memberikan porsi jam pelajaran lebih banyak dari pada mata pelajaran lainnya. Kebijakan pemerintah lainnya juga tercermin dalam Lampiran Peraturan Menteri Pendidikan Nasional Nomor 20 Tahun 2006 tentang Standar Isi yang berisi: "Tujuan diajarkannya matematika agar siswa memiliki kemampuan untuk: (1) memahami konsep matematika, menjelaskan keterkaitan antar konsep dan mengaplikasikan 
konsep atau algoritma secara luwes, akurat, efisien, dan tepat dalam pemecahan masalah, (2) menggunakan penalaran pada pola dan sifat, melakukan manipulasi matematika dalam membuat generalisasi, menyusun bukti, atau menjelaskan gagasan dan pernyataan matematika, (3) memecahkan masalah yang meliputi kemampuan memahami masalah, merangsang model matematika, menyelesaikan model dan menafsirkan situasi yang diperoleh, (4) mengomunikasikan gagasan dengan simbol, tabel, diagram, atau media lain untuk memperjelas keadaan atau masalah, dan (5) memiliki sikap menghargai kegunaan matematika dalam kehidupan yaitu memiliki rasa ingin tahu, perhatian, dan minat dalam mempelajari matematika, serta sikap ulet dan percaya diri dalam pemecahan masalah".

Meskipun pendidikan di Indonesia sudah bertujuan agar siswa memiliki minat dalam mempelajari matematika, tapi hal tersebut bertentangan dengan kondisi yang ada di lapangan. Masih terdapat sekolah-sekolah yang menggunakan pendekatan yang membuat minat belajar siswa terhadap mata pelajaran matematika masih kurang. Oleh karena itu, masih banyak siswa $\neg$ yang tidak merasa nyaman dan senang dalam mempelajari matematika. Siswa yang merasa nyaman dan senang akan berani untuk aktif dan akan mempunyai semangat yang lebih untuk terus belajar.

Usaha guru membuat siswa menjadi nyaman dan senang dalam mempelajari matematika dapat dilakukan dengan menerapkan pendekatan pembelajaran yang sesuai dengan masalah yang terjadi dalam pembelajaran, karakteristik siswa, dan materi pembelajaran. Oleh karena itu, kemampuan guru dalam mengolah dan menggunakan pendekatan pembelajaran sangat dibutuhkan. Meskipun demikian, kebanyakan guru hanya menggunakan pendekatan pembelajaran yang berpusat pada guru saja dan selalu melaksanakan pembelajaran di dalam kelas. Permasalahan tersebut juga terjadi di Sekolah Dasar Negeri Palang yang terletak di Desa Palang, Kecamatan Palang, Kabupaten Tuban. Hal tersebut didasarkan pada pengamatan peneliti sebagai pegawai di sekolah tersebut.

Berdasarkan pengamatan, peneliti menjumpai bahwa penggunaan pembelajaran teacher centered (berpusat pada guru) masih digunakan oleh guru Kelas IV Sekolah Dasar Negeri Palang yang terletak di Desa Palang, Kecamatan Palang, Kabupaten Tuban pada saat mengajarkan mata pelajaran matematika materi operasi hitung campuran. Guru tersebut secara aktif memberikan materi, memberi contoh, dan latihan sedangkan peserta didik hanya mendengar, mencatat, dan mengerjakan latihan. Hal tersebut membuat siswa lebih banyak mengobrol dan tidak sedikit juga siswa yang berpura-pura mendengarkan penjelasan guru. Hal tersebut terlihat ketika siswa hanya terdiam dan tidak bisa menjawab pertanyaan guru tentang materi yang baru dijelaskan.

Permasalahan di atas berbeda ketika mata pelajaran pendidikan jasmani, olahraga, dan kesehatan (penjasorkes) diajarkan. Para siswa sangat antusias dan bersemangat pada saat mata pelajaran penjasorkes berlangsung. Hal tersebut menandakan minat belajar siswa terhadap mata pelajaran penjasorkes lebih tinggi daripada mata pelajaran matematika materi operasi hitung campuran.

Minat belajar siswa Kelas IV Sekolah Dasar Negeri Palang yang terletak di Desa Palang, Kecamatan Palang, Kabupaten Tuban terhadap materi operasi hitung campuran rendah. Hal tersebut dikarenakan mereka hanya dianggap sebagai objek pembelajaran yang pasif dan hanya mengerjakan tugas yang diberikan oleh guru. Hal tersebut didukung dengan pernyataan guru kelasnya. Guru kelas tersebut menyatakan bahwa meskipun semua peserta didik kelas IV memiliki nilai minimal KKM (Kriteria Ketuntasan Minimal) pada materi operasi hitung campuran, tetapi nilai itu didapatkan dengan berkali-kali remidi dan ada beberapa anak yang nilainya tetap di bawah KKM, maka terpaksa memberikan nilai pada beberapa anak tersebut di batas KKM. Hal tersebut dilakukan karena jika nilai berada di bawah KKM, maka beberapa anak tersebut tidak dapat naik kelas.

Dengan melihat masalah yang dihadapi guru dan siswa dalam pembelajaran operasi hitung campuran, maka perlu adanya pengubahan pendekatan pembelajaran yang mulanya pembelajaran konvensional diubah menjadi pembelajaran yang menyenangkan. Pengubahan pembelajaran konvensional menjadi pembelajaran yang menyenangkan dapat menumbuhkan minat belajar siswa sehingga siswa dapat dengan mudah memahami materi yang diajarkan oleh gurunya serta prestasi belajar siswa juga meningkat sehingga efektivitas pembelajaran tercapai.

Hal yang perlu mendapat perhatian yaitu bagaimana membuat materi operasi hitung campuran menjadi materi yang menyenangkan dan diminati siswa. Pentingnya membuat materi operasi hitung campuran menjadi materi yang menyenangkan dan dimintai siswa adalah agar siswa dapat menguasai materi tersebut. Salah satu upaya yang dapat digunakan untuk membuat materi operasi hitung campuran agar menyenangkan dan diminati siswa yaitu dengan menggunakan pembelajaran matematika realistik.

Pembelajaran Matematika Realistik (PMR) adalah sebuah pendekatan belajar matematika yang dikembangkan sejak tahun 1971 oleh sekelompok ahli matematika dari Freudenthal Institute, Utrecht University di Belanda (Hadi, 
2005:7). Dengan pendekatan ini siswa tidak hanya mudah menguasai konsep dan materi pelajaran namun juga tidak cepat lupa dengan apa yang telah diperolehnya tersebut (Soviawati, 2011:84). Hal tersebut dikarenakan dalam PMR, siswa tidak boleh dipandang sebagai passive receivers of ready-made mathematics (Freudental dalam Hadi, 2005:7). Maksudnya adalah siswa seharusnya tidak sebagai penerima pasif matematika yang sudah jadi. Hal tersebut diperkuat oleh pendapat Castle \& Needham (2007) bahwa pembelajaran matematika untuk Taman KanakKanak dan Sekolah Dasar harus didasarkan pada kegiatan ataupun pengalaman yang bermakna dimana pengetahuan informal siswa dihubungkan dengan konsep formal matematika. Oleh karena itu, dalam mengajarkan materi operasi hitung campuran seharusnya diawali dengan suatu konteks atau permasalahan realistik sehingga siswa dapat menggunakan pengetahuan informalnya untuk menyelesaikan masalah tersebut.

Wijaya (2012:21) menjelaskan bahwa konteks atau permasalahan realistik digunakan sebagai titik awal pembelajaran matematika dan konteks tersebut tidak harus berupa masalah dunia nyata, namun bisa dalam bentuk permainan, penggunaan alat peraga, atau situasi lain selama hal tersebut bermakna dan bisa dibayangkan dalam pikiran siswa. Di Indonesia, terdapat berbagai macam permainan yang memuat konsep-konsep matematika sehingga permainan-permainan tersebut dapat dimanfaatkan dalam mangajarkan mata pelajaran matematika. Lebih lanjut Wijaya menjelaskan bahwa permainan untuk pembelajaran matematika dapat memberikan tiga macam manfaat, yaitu: (1) manfaat motivasional, (2) manfaat sosial dan (3) manfaat konseptual. Manfaat motivasional diperoleh karena permainan bersifat atraktif. Keatraktifan permainan dapat merangsang motivasi personal siswa serta kepuasan dalam pembelajaran sehingga siswa akan memiliki minat belajar matematika. Bentuk permainan secara berkelompok ataupun berpasangan akan memberikan manfaat sosial. Kerja sama dan komunikasi yang terbentuk dalam permainan dapat mendorong berkembangnya kolaborasi dan interaktivitas siswa dalam belajar. Manfaat konseptual tercapai karena permainan merupakan suatu media yang efektif untuk meningkatkan pembelajaran dan pemahaman suatu konsep matematika.

Salah satu permainan yang dapat digunakan sebagai konteks atau permasalahan realistik dan memiliki relevansi dengan materi operasi hitung campuran adalah permainan gatrik. Hal tersebut dikarenakan dalam memainkan permainan gatrik memerlukan operasi hitung campuran untuk menentukan skor dan menentukan pemenangnya. Permainan gatrik merupakan permainan yang dimainkan oleh dua orang atau dua regu yang beranggotakan beberapa orang dengan menggunakan tongkat pemukul terbuat dari kayu dan potongan kayu sepanjang seperempat tongkat pemukul sebagai alat permainannya (Kartodiwirio dan Abadi, 2005:348). Permainan gatrik juga merupakan permainan tradisional yang biasa dilakukan oleh anak-anak di Desa Palang Kecamatan Palang Kabupaten Tuban. Oleh karena itu, menjadikan permainan gatrik sebagai konteks Pembelajaran Matematika Realistik (PMR) materi operasi hitung campuran pada penelitian ini akan membuat siswa Kelas IV Sekolah Dasar Negeri Palang yang terletak di Desa Palang, Kecamatan Palang, Kabupaten Tuban merasa nyaman dan tidak tertekan. Selain itu, penerapan permainan gatrik tersebut juga dapat meningkatkan minat belajar siswa tersebut.

Berdasarkan uraian di atas, peneliti berupaya mengetahui efektivitas pembelajaran matematika realistik dengan permainan gatrik pada operasi hitung campuran di Kelas IV SD. Berdasarkan uraian di atas, peneliti berupaya mengetahui efektivitas pembelajaran matematika realistik dengan permainan gatrik pada operasi hitung campuran di Kelas IV SD.

\section{TINJAUAN PUSTAKA}

Miarso (dalam Uno, 2013:173) menjelaskan bahwa pembelajaran yang efektif adalah pembelajaran yang dapat menghasilkan belajar yang bermanfaat dan terfokus pada siswa (student centered) melalui penggunaan prosedur yang tepat. Definisi tersebut mengandung arti bahwa pembelajaran yang efektif terdapat dua hal yang penting, yaitu terjadinya belajar pada siswa dan apa yang dilakukan guru untuk membelajarkan siswa. Terjadinya belajar pada siswa berupa aktivitas siswa, respon siswa, dan hasil belajar siswa. Sedangkan apa yang dilakukan guru untuk membelajarkan siswa berupa kemampuan guru dalam mengelola pembelajaran.

Pembelajaran yang efektif penting untuk diperhatikan oleh guru. Hal itu dikarenakan pembelajaran mempunyai dua dampak bagi siswa. Dampak pertama adalah dampak langsung pendidikan, dalam hal ini adalah nilai yang didapatkan oleh siswa. Dampak kedua adalah eksistensi siswa tersebut menjadi anggota masyarakat. Oleh karena itu, sebagai guru sangat mengharapkan keefektifan pembelajaran dapat dicapai dengan baik.

Beberapa ahli menentukan indikator keefektifan pembelajaran, diantaranya adalah Slavin (2009), Eggen dan Kauchak (1996), Diamon (dalam Mudhoffir, 1990), serta Hamiyah dan Jauhar (2014). Slavin (2009:197) mengatakan bahwa efektifitas suatu pembelajaran dapat ditinjau dari empat indikator, yaitu: 
1. Kualitas pembelajaran (quality of instruction)

Kualitas pembelajaran yang memudahkan siswa dalam memahami materi pembelajaran

2. Kesesuaian tingkat pembelajaran (appropriate levels of instruction)

Kemampuan guru untuk memastikan kesiapan siswa dalam mempelajari materi baru.

3. Insentif (incentive)

Kemampuan guru membangkitkan siswa untuk terlibat aktif dalam pembelajaran, seperti melaksanakan tugas yang diberikan guru, mempelajari materi yang disampaikan guru.

4. Waktu (time)

Banyaknya waktu yang disediakan kepada siswa untuk mempelejari materi yang diberikan.

Eggen dan Kauchak (1996:28) mengatakan bahwa pembelajaran dikatakan efektif apabila siswa secara aktif dilibatkan dalam pengorganiasasian dan penemuan informasi (pengetahuan). Semakin aktif siswa dalam pembelajaran maka ketercapauan ketuntasan siswa semakin besar sehingga pembelajaran juga semaki efektif. Sedangkan, Diamon (dalam Mudhofir, 1990:164) mengatakan bahwa efektifitas model pembelajaran juga dapat diukur dengan melihat minat siswa terhadap kegiatan pembelajaran serta diharapkan hasil belajar siswa akan lebih baik jika siswa belajar sesuai dengan minatnya.

Hamiyah dan Jauhar (2014:273) menentukan kriteria efektifitas pembelajaran diantaranya adalah: (1) ketuntasan belajar siswa sekurang-kurangnya $75 \%$ dari jumlah siswa semua siswa, (2) siswa telah memeroleh nilai $\geqslant 60$ dalam peningkatan hasil belajar, (3) secara statistik, hasil belajar siswa menunjukkan perbedaan yang signifikan antara pemahaman awal dengan pemahaman setelah pembelajaran, dan (3) model pembelajaran dikatakan efektif jika dapat meningkatkan minat dan motivasi sswa.

Berdasarkan uraian di atas, secara keseluruhan pembelajaran dikatakan efektif apabila memenuhi indikator sebagi berikut:

1. Pembelajaran dapat dilaksanakan guru dengan baik

2. Aktivitas siswa dalam pembelajaran efektif.

3. Respon siswa terhadap perangkat pembelajaran positif.

4. Ketuntasan hasil belajar siswa secara klasikal tercapai.

\section{METODE}

Pada penelitian ini, peneliti menggunakan perangkat pembelajaran matematika realitik dengan permainan gatrik pada operasi hitung campuran di Kelas IV SD yang sudah dekmbangkan oleh Alkulub (2016). Perangkat pembelajaran yang digunakan telah memenuhi unsur kevalidan dengan setiap kategori validasi mendapat nilai minimal 3 (Alkulub, 2016:114). Penelitian dilaksanakan di kelas IV SD Negeri Palang Kabupaten Tuban. Banyaknya siswa yang menjadi subjek penelitian ini adalah 28 siswa.

Teknik pengumpulan data dalam penelitian ini dilakukan dengan pengamatan, angket, dan tes. Pengeamatan dilakukan untuk mengetahui keterlaksanaan pembelajaran oleh guru dan mengetahui aktivitas siswa selama pembelajaran. Angket dilakukan untuk mengetahui respon siswa. Tes digunakan untuk mengetahui ketuntasan belajar siswa secara klasikal.

Instrumen yang dikembangkan untuk mengumpulkan data dalam penelitian ini adalah lembar pengamatan keterlaksanaan pembelajaran oleh guru, lembar pengamatan aktivitas siswa, lembar angket siswa, dan tes.

Data hasil pengamatan keterlaksanaan pembelajaran oleh guru dianalisis dengan skor minimal, yaitu pembelajaran dapat dilaksanakan dengan baik oleh guru jika setiap kategori pengamatan mendapat nilai miniamal 3. Sedangkan data hasil pengamatan aktivitas siswa, respon siswa, dan tes dianalisis dengan persentase. Aktivitas siswa dikatakan efektif jika hasil peghitungan persentasenya nilainya minimal $75 \%$. Respon siswa dikatakan positif jika hasil peghitungan persentasenya nilainya minimal $75 \%$. Tes hasil belajar siswa secara klisakal tercapai jika $\geq 75 \%$ siswa tuntas belajar.

\section{HASIL PENELITIAN}

\section{Keterlaksanaan pembelajaran oleh guru}

Rekapitulasi hasil pengamatan keterlaksanaan pembelajaran matematika realistik dengan permainan gatrik dapat dilihat melalui tabel berikut ini:

Tabel 1 Hasil pengamatan keterlaksanaan pembelajaran oleh guru

\begin{tabular}{|c|c|c|c|}
\hline \multirow{2}{*}{ No } & \multirow{2}{*}{ Kegiatan Guru } & \multicolumn{2}{|c|}{ Skor } \\
\hline & & P1 & $\mathbf{P 2}$ \\
\hline $\mathbf{A}$ & Pendahuluan & & \\
\hline 1 & $\begin{array}{l}\text { Memotivasi siswa dan } \\
\text { mengemukakan tujuan } \\
\text { pembelajaran }\end{array}$ & 4 & 4 \\
\hline 2 & $\begin{array}{l}\text { Menghubungakan materi hari ini } \\
\text { dengan materi sebelumnya }\end{array}$ & 3 & 4 \\
\hline \multirow{2}{*}{ No } & Kegiatan Guru & \multicolumn{2}{|c|}{ Skor } \\
\hline & & P1 & $\mathbf{P 2}$ \\
\hline B & Kegiatan Inti & & \\
\hline 1 & $\begin{array}{l}\text { Menjelaskan konteks/ masalah } \\
\text { realistik }\end{array}$ & 4 & 4 \\
\hline 2 & $\begin{array}{l}\text { Mengarahkan siswa untuk } \\
\text { menemukan sendiri jawaban dan } \\
\text { cara menjawab soal dengan } \\
\text { memberikan bantuan terbatas }\end{array}$ & 4 & 3 \\
\hline 3 & Mengamati aktivitas siswa dalam & 4 & 4 \\
\hline
\end{tabular}




\begin{tabular}{|c|c|c|c|}
\hline 4 & $\begin{array}{l}\text { menyelesaikan masalah realistik } \\
\text { Mengoptimalkan interaksi siswa } \\
\text { dalam bekerja }\end{array}$ & 4 & 3 \\
\hline 5 & $\begin{array}{l}\text { Mendorong siswa untuk } \\
\text { membandingan jawaban dengan } \\
\text { jawaban teman }\end{array}$ & 3 & 4 \\
\hline 6 & $\begin{array}{l}\text { Memimpin diskusi kelas/ } \\
\text { menguasai kelas }\end{array}$ & 4 & 3 \\
\hline 7 & $\begin{array}{l}\text { Menghargai berbagai pendapat } \\
\text { siswa }\end{array}$ & 4 & 4 \\
\hline 8 & $\begin{array}{l}\text { Mengarahkan siswa untuk } \\
\text { menemukan sendiri dan menarik } \\
\text { kesimpulan tentang konsep/ } \\
\text { prinsip/ prosedur/ teorema } \\
\text { matematika }\end{array}$ & 3 & 3 \\
\hline 9 & $\begin{array}{l}\text { Mendorong siswa untuk mau } \\
\text { bertanya, mengeluarkan } \\
\text { pendapat, atau menjawab } \\
\text { pertanyaan. }\end{array}$ & 3 & 3 \\
\hline C & Kegiatan Akhir & & \\
\hline 1 & $\begin{array}{l}\text { Mengarahkan siswa untuk } \\
\text { membuat rangkuman materi }\end{array}$ & 4 & 3 \\
\hline 2 & $\begin{array}{l}\text { Menyampaikan judul materi } \\
\text { berikutnya, PR, dan menutup } \\
\text { pelajaran }\end{array}$ & 4 & 3 \\
\hline
\end{tabular}

Berdasarkan rekapitulasi hasil pengamatan keterlaksanaan pembelajaran oleh guru, skor minimal yang didapat adalah 3. Dengan demikian, dapat dinyatakan bahwa pembelajaran dapat dilaksanakan guru dengan baik.

\section{Aktivitas siswa}

Hasil pengamatan aktivitas siswa selama pembelajaran dalam dua kali pertemuan dinyatakan dengan persentase. Hasil tersebut dapat dilihat sebagai berikut:

Tabel 2 Hasil pengamatan aktivitas siswa

\begin{tabular}{|c|c|c|c|}
\hline \multirow{2}{*}{ No } & \multirow{2}{*}{ Kategori pengamatan } & \multicolumn{2}{|c|}{$\begin{array}{c}\text { Persentase } \\
\text { aktifitas siswa }\end{array}$} \\
\hline & & $\begin{array}{l}\text { P1 } \\
(\%)\end{array}$ & $\begin{array}{l}\mathrm{P} 2 \\
(\%)\end{array}$ \\
\hline 1 & $\begin{array}{l}\text { Mendengarkan atau } \\
\text { memperhatikan penjelasan } \\
\text { guru atau teman. }\end{array}$ & 83,33 & 83,33 \\
\hline 2 & $\begin{array}{l}\text { Membaca atau memahami } \\
\text { masalah kontekstual yang } \\
\text { diberikan guru. }\end{array}$ & 83,33 & 83,33 \\
\hline 3 & $\begin{array}{l}\text { Menyelesaikan masalah } \\
\text { kontekstual }\end{array}$ & 83,33 & 83,33 \\
\hline 4 & $\begin{array}{l}\text { Bertanya atau menyiapkan ide } \\
\text { (pendapat) kepada teman/ } \\
\text { guru. }\end{array}$ & 66,67 & 83,33 \\
\hline 5 & $\begin{array}{l}\text { Membandingkan jawaban } \\
\text { dalam diskusi kelompok atau } \\
\text { diskusi kelas }\end{array}$ & 83,33 & 83,33 \\
\hline 6 & Membuat kesimpulan atau & 83,33 & 83,33 \\
\hline
\end{tabular}

\begin{tabular}{lcc}
\hline rangkuman dengan bimbingan & & \\
guru & 483,3 & 500,0 \\
Jumlah & 3 & 0 \\
\hline
\end{tabular}

Berdasarkan data hasil pengamatan aktivitas siswa di atas dapat dihitung persentase aktivitas siswa sebagai berikut:

Persentase aktivitas siswa pertemuan 1:

$$
\frac{49 a_{2} \mathrm{a} a 96}{600}=80,56 \%
$$

Persentase aktivitas siswa pertemuan 2

$$
\frac{500,0096}{600}=83,33 \%
$$

Hasil persentase aktivitas siswa pada dalam dua pertemuan termasuk dalam kategori sangat baik (81\% 100\%). Dengan demikian, aktivitas siswa dalam pembelajaran dapat dikatakan efektif.

\section{Respon siswa}

Berikut merupakan respon siswa yang diambil di akhir pertemuan pembelajaran matematika realistik dengan permainan gatrik. Secara ringkas dapat dilihat melalui tabel

\begin{tabular}{|c|c|c|}
\hline $\begin{array}{c}\text { No } \\
\text { Butir } \\
\text { Anoket }\end{array}$ & Pertanyaan Angket & $\begin{array}{l}\text { Skor } \\
(\%)\end{array}$ \\
\hline 1 & $\begin{array}{l}\text { Apakah kamu merasa senang } \\
\text { terhadap materi yang dipelajari? }\end{array}$ & 75,00 \\
\hline $\begin{array}{c}\text { No } \\
\text { Butir } \\
\text { Angket }\end{array}$ & Pertanyaan Angket & $\begin{array}{l}\text { Skor } \\
(\%)\end{array}$ \\
\hline 2 & $\begin{array}{l}\text { Apakah kamu merasa senang } \\
\text { terhadap komponen dalam LKS? }\end{array}$ & 85,71 \\
\hline 3 & $\begin{array}{l}\text { Apakah kamu merasa senang } \\
\text { terhadap suasana belajar yang telah } \\
\text { dilaksanakan? }\end{array}$ & 82,14 \\
\hline 4 & $\begin{array}{l}\text { Apakah materi pokok yang } \\
\text { dipelajari tergolong materi baru? }\end{array}$ & 85,71 \\
\hline 5 & $\begin{array}{l}\text { Apakah bentuk LKS yang kamu } \\
\text { pelajari merupakan bentuk LKS } \\
\text { baru? }\end{array}$ & 64,29 \\
\hline 6 & $\begin{array}{l}\text { Apakah kamu merasa bahwa } \\
\text { suasana pembelajaran yang baru } \\
\text { dilaksanakan termasuk susasana } \\
\text { pembelajaran yang baru? }\end{array}$ & 75,00 \\
\hline 7 & $\begin{array}{l}\text { Apakah cara guru mengajar } \\
\text { merupakan model pembelajaran } \\
\text { yang baru? }\end{array}$ & 89,29 \\
\hline 8 & $\begin{array}{l}\text { Apakah kamu dapat memahami } \\
\text { bahasa yang digunakan dalam } \\
\text { LKS? }\end{array}$ & 89,29 \\
\hline 9 & $\begin{array}{l}\text { Apakah kamu tertarik terhadap } \\
\text { penampilan dalam LKS seperti }\end{array}$ & 64,29 \\
\hline
\end{tabular}
sebagai berikut:

Tabel 3 Persentase respon siswa 


\begin{tabular}{clc}
\hline & \multicolumn{1}{c}{ ilustrasi gambar, letak gambar, dan } & \\
& tulisan? \\
& Apakah kamu merasa senang & \\
10 & $\begin{array}{l}\text { terhadap pembelajaran matematika } \\
\text { realistik yang baru saja dilakukan? }\end{array}$ & 82,14 \\
& $\begin{array}{l}\text { Apakah kamu berminat untuk } \\
\text { mengikuti pembelajaran }\end{array}$ & \\
11 & $\begin{array}{l}\text { matematika realistik pada materi } \\
\text { selanjutnya seperti apa yang baru } \\
\text { saja dilakukan? }\end{array}$ & 64,29 \\
Jumlah & & 857,14 \\
\hline
\end{tabular}

Berdasarkan data hasil respon siswa di atas dapat dihitung persentase respon siswa sebagai berikut:

Persentase respon siswa: $\frac{857_{2} 1486}{1100}=77,92 \%$

Hasil persentase respon siswa tersebut termasuk dalam kategori baik (61\% - 80\%). Dengan demikian, respon siswa terhadap perangkat pembelajaran dapat dikatakan positif.

\section{Tes Hasil Belajar}

Berikut merupakan data tes hasil belajar siswa:

Tabel 4.4 nilai tes hasil belajar

\begin{tabular}{|c|c|}
\hline $\begin{array}{c}\text { No Urut } \\
\text { Siswa }\end{array}$ & Nilai \\
\hline 1 & 85 \\
\hline 2 & 80 \\
\hline 3 & 75 \\
\hline 4 & 85 \\
\hline 5 & 70 \\
\hline 6 & 80 \\
\hline 7 & 100 \\
\hline 8 & 65 \\
\hline 9 & 75 \\
\hline 10 & 90 \\
\hline 11 & 75 \\
\hline 12 & 65 \\
\hline 13 & 85 \\
\hline 14 & 55 \\
\hline 15 & 80 \\
\hline 16 & 75 \\
\hline 17 & 80 \\
\hline 18 & 80 \\
\hline 19 & 65 \\
\hline 20 & 85 \\
\hline 21 & 80 \\
\hline 22 & 80 \\
\hline 23 & 80 \\
\hline 24 & 70 \\
\hline 25 & 80 \\
\hline 26 & 80 \\
\hline 27 & 75 \\
\hline 28 & 75 \\
\hline
\end{tabular}

Berdasarkan data di atas terdapat 22 anak atau $78,57 \%$ anak dari semua yang mengikuti tes mendapatkan nilai di atas KKM (75). Dengan demikian, ketuntasan belajar siswa secara klasikal tercapai.

Berdasarkan hasil analisis data di atas dapat diketahui bahwa pembelajaran dapat dilaksanakan oleh guru dengan baik, aktivitas siswa efektif dalam pembelajaran, respon siswa positif terhadap pembelajaran, dan ketuntasan belajar siswa secara klasikal tercapai. Dengan demikian, dapat dikatakan bahwa pembelajaran matematika realistik dengan permainan gatrik efektif digunakan pada materi operasi hitung campuran kelas IV.

\section{Pembahasan}

\section{Keterlaksanaan pembelajaran oleh guru}

Hasil pengamatan keterlaksanaan pembelajaran matematika realistik dengan permainan gatrik oleh guru disajikan pada tabel 1. Berdasarkan hasil tersebut menunjukkan bahwa pembelajaran dapat dilaksanakan oleh guru selama dua kali pertemuan. Guru aktif dalam mengarahkan, memotivasi, memberikan pertanyaan timbal balik kepada siswa dengan tujuan agar siswa lebih mudah memahami dan menyelesaikan masalah mengenai operasi hitung campuran.

Gambar di bawah ini menunjukkan sekilas suasana pembelajaran matematika realistik dengan permainan gatrik yang dilaksanakan di kelas ujicoba maupun kelas implementasi.

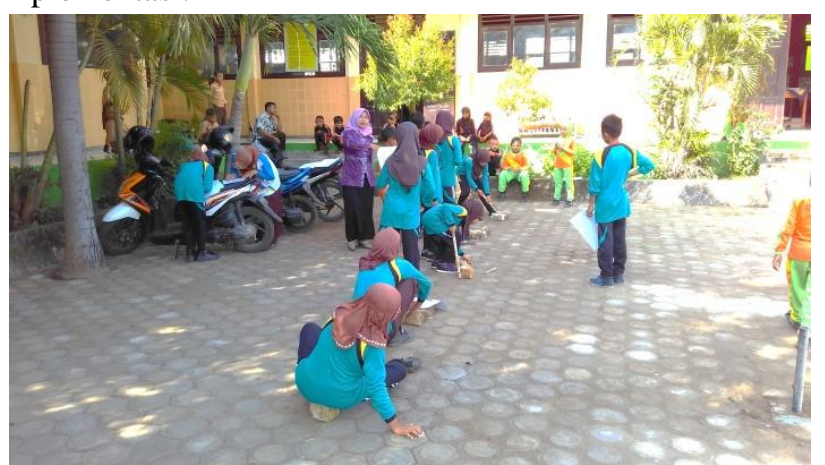

Gambar 1 Guru memberikan arahan kepada siswa dalam bermain gatrik

Guru sangat aktif dalam melaksanakan pembelajaran ini. Guru memberikan arahan kepada siswa dalam bermain gatrik sehingga siswa termotivasi dalam mengikuti pembelajaran ini. Hal tersebut sejalan dengan pendapat Hadi (2005:39) yang mengatakan bahwa peran guru dalam pembelajaran matematika realistik sebagai fasilitator, mampu membangun pengajaran yang interaktif, memberikan kesempatan kepada siswa untuk secara aktif menyumbang pada proses belajar dirinya dan secara aktif 
membantu siswa dalam menafsirkan permasalahan realistik.

Setelah melakukan permainan, siswa menyelesaikan masalah yang terdapat dalam permainan gatrik yang berhubungan dengan operasi hitung campuran seperti pada gambar di bawah ini.

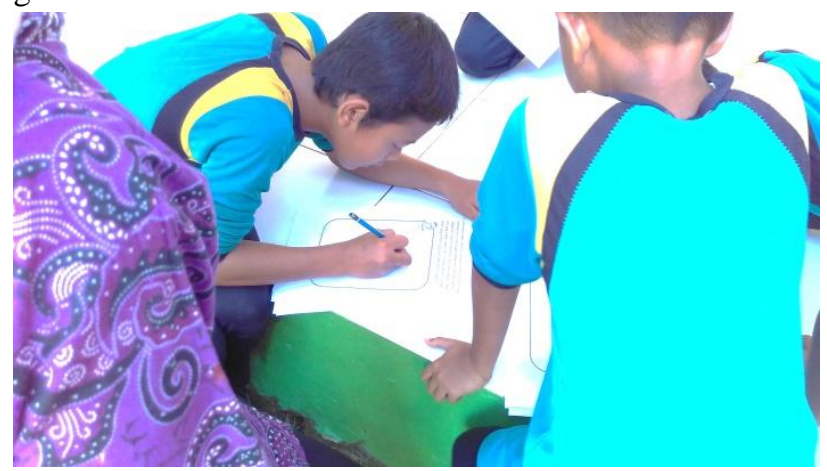

Gambar 2 Salah satu siswa menyelesaikan masalah yang berkaitan dengan operasi hitung campuran

Setelah siswa selesai menyelesaikan masalah yang berkaitan dengan operasi hitung campuran. Hasil pengerjaannya tersebut ditempel di dinding kelas untuk didiskusikan bersama seperti pada gambar berikut:

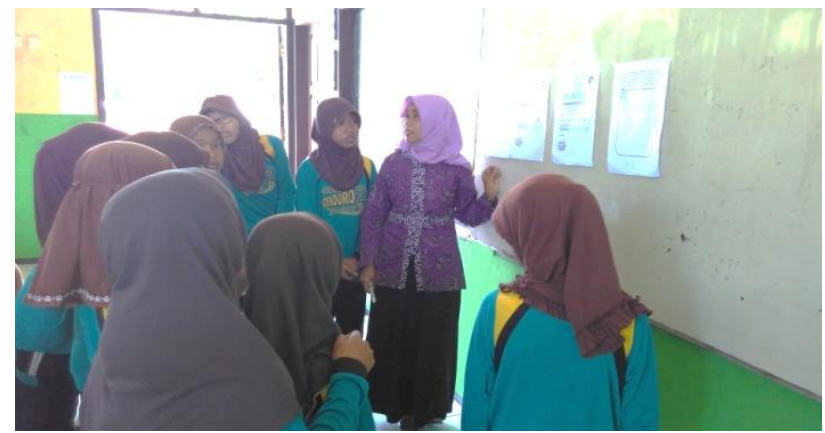

Gambar 3 Guru bersama siswa mendikusikan hasil pekerjaan siswa

Pada gambar di atas dapat dilihat bahwa guru sedang memberikan penjelasan kepada para siswa berdasarkan hasil pengerjaan salah satu siswa. Treffers (dalam Wijaya, 2012:22) menjelaskan bahwa salah satu karakteristik pembelajaran matematika realistik adalah pemanfaatan hasil konstruksi siswa. Pada materi operasi hitung campuran yang terdapat pada permainan gatrik, pada awalnya siswa diberi kebebasan penuh untuk menghitung skor kelompoknya dari level pertama sampai level terakhir beserta dengan skor hukuman dan skor bonusnya. Setelah itu dari semua proses pengerjaan siswa, guru membimbing para siswa dengan proses operasi hitung campuran dengan cara formal, yaitu guru membimbing siswa dalam menemukan prosedur matematika, seperti penjumlahan bersusun.

\section{Aktivitas Siswa}

Hasil analisis pengamatan aktivitas siswa dapat dilihat pada tabel 4.2. Hasil analisis pengamatan aktivitas siswa mendapatkan nilai persentase sebesar $80,56 \%$ pada pertemuan pertama dan $83,33 \%$ pada pertemuan kedua. Berdasarkan hasil tersebut menunjukkan bahwa aktivitas siswa efektif dalam pembelajaran ketika implementasi perangkat pembelaran.

Pada saat berlangsungnya pembelajaran siswa sangat antusias untuk mengikuti pembelajaran. Siswa antusias mendengarkan guru dalam menjelaskan langkahlangkah permainan gatrik seperti pada gambar berikut:

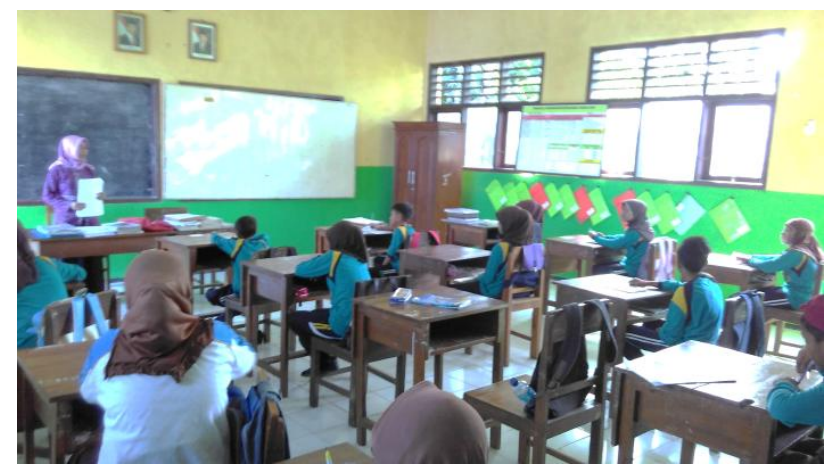

Gambar 4 Suasana pembelajaran di dalam kelas

Pada gambar terlihat siswa sangat antusias mendengarkan guru dalam mengarahkan langkah-langkah permainan gatrik. Arahan dilakukan guru agar siswa lebih bersemangat dalam bermain gatrik dan dapat menyelesaikan permasalahan yang ada dalam LKS. Dalam permainan gatrik siswa melakukan secara berpasangan. Guru menyediakan tempat untuk melakukan permainan gatrik seperti pada gambar di bawah ini:

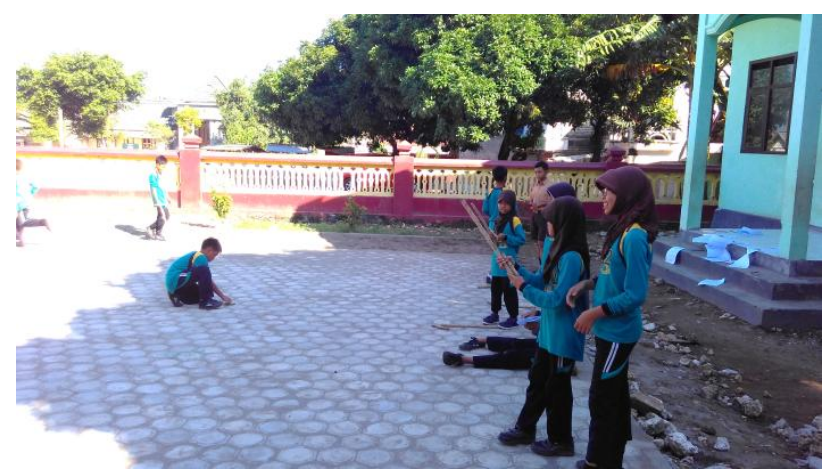

Gambar 5 Siswa melakukan permainan gatrik

Setelah melakukan permainan gatrik, siswa menyelesaikan masalah yang terdapat dalam LKS, yaitu menentukan skor yang didapatnya. Dalam menghitung skor ini siswa diarahkan untuk diselesaikan secara sendiri 
dengan menggunakan caranya sendiri. Tapi, siswa juga diarahkan berdiskusi dengan pasangan maupun lawan bermainnya. Hal ini sejalan dengan salah satu teori Vygostki yaitu Zone of Proximal Development (ZPD). Menurut Vygotsky (dalam Gunawan, 2015) ZPD menitikberatkan pada interaksi sosial akan dapat memudahkan perkembangan anak. Ketika siswa mengerjakan pekerjaanya di sekolah sendiri, perkembangan mereka kemungkinan akan berjalan lambat. Siswa seharusnya bekerja dengan teman yang lebih terampil yang dapat memimpin secara sistematis dalam memecahkan masalah yang lebih kompleks. Di bawah ini merupakan gambar yang menunjukkan pengerjaan siswa dalam menyelesaikan operasi hitung campuran dalam permainan gatrik.

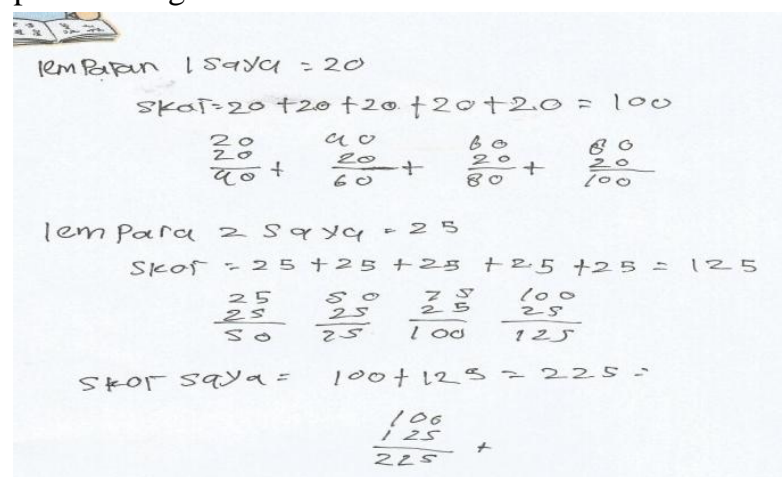

Gambar 6 pengerjaan operasi hitung campuran dalam

\section{LKS}

Setelah semua siswa menyelesaikan masalahnya, mereka diarahkan untuk berdiskusi di dalam kelas bersama dengan teman dan guru. Cara dan hasil penyelesaian masalah tersebut dijadikan dasar atau bahan diskusi. Selain itu, cara penyelesaian masalah tersebut digunakan sebagai dasar untuk menemukan prosedur matematika secara formal seperti melakukan operasi hitung campuran dengan cara bersusun.

\section{Respon Siswa}

Hasil analisis respon siswa pada penelitian ini dapat diketahui bahwa siswa memberi respon positif. Untuk mengetahui respon siswa, peneliti memberikan angket respon siswa terhadap pembelajaran kepada semua siswa yang telah mengikuti pembelajaran matematika realistik dengan permainan gatrik baik pada kelas ujicoba maupun pada kelas implementasi.

Pertanyaan angket respon siswa yang diberikan kepada semua siswa yang mengikuti pembelajaran. Banyaknya butir pertanyaan angket respon siswa tersebut adalah 11 butir. Siswa dapat menjawab pertanyaan angket respon siswa tersebut dengan memilih jawaban ya atau tidak. Setiap jawaban ya mendapat nilai 1 dan setiap jawaban tidak mendapat nilai 0 .

Hasil dari angket respon siswa yang sudah dijawab tersebut kemudian dianalisis dengan menghitung rata-rata nilai setiap butir pertanyaan angket respon siswa. Rata-rata setiap butir soal tersbut dihitung persentasenya dengan menjumlahkan rata-rata nilai setiap butir pertanyaan angket dibagi banyaknya soal kemudian dikali $100 \%$.

Hasil persentase respon siswa adalah 77,92\%. Hasil persentase respon siswa tersebut termasuk kategaori baik $(61 \%$ - 80\%). Dengan hasil tersebut dapat dikatakan bahwa repon siswa pada tahap implementasi perangkat pembelajaran adalah positif.

Ahmadi (1999:166) menjelaskan bahwa respon positif merupakan sebuah bentuk respon, tindakan, atau sikap yang menunjukkan atau memperlihatkan, menerima, mengakui, menyetujui, serta melaksanakan aturan-aturan yang berlaku dimana individu itu berada. Berdasarkan hasil analisis respon siswa dalam penelitian ini, dapat dikatakan bahwa siswa menerima, mengakui, menyetujui, serta melaksanakan aturan-aturan yang berlaku pada pembelajaran matematika realistik..

\section{Hasil Belajar}

Untuk mengetahui hasil belajar siswa dilakukan dengan memberikan tes hasil belajar siswa pada akhir pertemuan 2. Tes hasil belajar tersebut terdiri dari 5 butir pertanyaan. Selain itu, tes hasil belajar tersebut telah divalidasi oleh validator sebelum diberikan kepada siswa. Di bawah ini merupakan gambar hasil tes hasil belajar siswa.

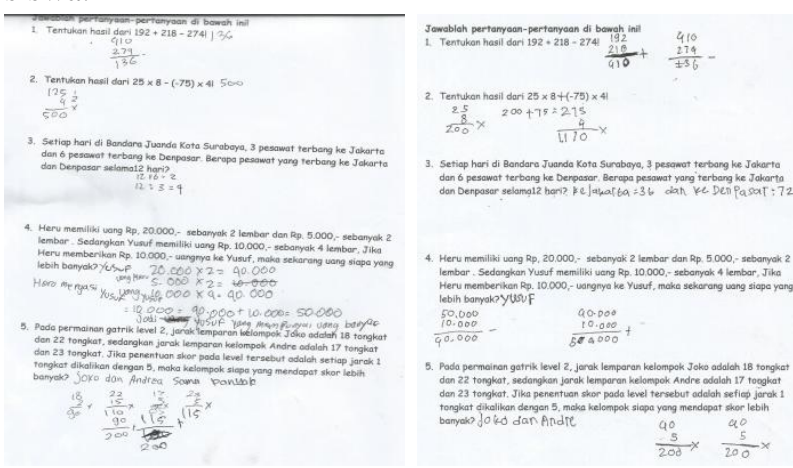

Gambar 7 Pengerjaan THB siswa

Hasil tes hasil belejar tersebut kemudian dianalisis untuk mengetehui ketuntasan belajar siswa secara klasikal. Analisis data hasil belajar siswa yang tuntas belajar sebanyak 78,57 \% atau 22 siswa dari 28 siswa yang mengikuti tes. Rata-rata nilai tes hasil belajar siswa meningkat menjadi 77,5. 
Hamiyah dan Jauhar (2014:273) berpendapat bahwa ketuntasan belajar siswa sekurang-kurangnya $75 \%$ dari jumlah siswa semua siswa yang mengikuti tes. Berdasarkan hasil analisis tes hasil belajar siswa, banyaknya siswa yang tuntas belajar pada ujicoba perangkat pembelajaran dan pada tahap implementasi perangkat pembelajaran adalah lebih dari $75 \%$ dari semua siswa yang mengikuti tes. Dengan demikian, dapat disimpulkan bahwa ketuntasan belajar siswa secara klasikal tercapai.

\section{SIMPULAN}

Pembelajaran matematika realistik dengan permainan gatrik efektif digunakan pada materi operasi hitung campuran di kelas IV SD. Hal tersebut dibuktikan dengan hasil penelitian pada kelas implementasi diantaranya adalah keterlaksanaan pembelajaran yang dilakukan guru dikategorikan baik karena setiap indikaotor mendapat nilai $\geqslant 3$, setiap kategori aktivitas siswa termasuk dalam waktu idel sehingga aktivitas siswa dikatakan efektif, respon siswa positif terhadap pembelajaran yaitu $77,92 \%$, Ketuntasan belajar siswa secara klasikal tercapai yaitu $78,57 \%$ siswa mendapatkan nilai di atas KKM.

Pembelajaran matematika realistik dengan permainan gatrik hendaknya digunakan guru dalam mengajarkan operasi hitung campuran kepada siswa kelas IV SD. Hal tersebut dikarenakan pembelajaran tersebut sudah sudah dinyatakan efektif digunakan untuk mengajarkan materi operasi hitung campuran kepada siswa kelas IV SD.

\section{DAFTAR PUSTAKA}

Abdurrahman, M. (2003). Pendidikan bagi anak berkesulitan belajar. Jakarta: Rineka Cipta

Ahmadi. (1999). Psikologi sosial. Bandung: PT Rineka Cipta.

Arikunto, S. (2002). Metodologi Penelitian. Bandung: PT Rineka Cipta.

Badan Standar Nasional Pendidikan. (2006). Lampiran permendiknas no.22 tahun 2006 tentang standar isi untuk satuan pendidikan dasar dan menengah. Jakarta: Depdiknas

Castle, K. \& Needham, J. (2007). First graders understanding of measurement. Early Childhood Education Journal, 35 (3), 215-221

Eggen, P. \& Kauchak, D. (1996). Strategies for teaching conten and thinking skill. Third Edition. Boston: Ailyn and Bacon Publishers.
Gravemeijer, K. P. E. (1994). Developing realistic mathematics education. Utrecht: Freudenthal Institute.

Gunawan, B. (2015). Penerapan teori belajar vygotsky dalam interaksi belajar mengajar. Diakses di http://www.kompasiana.com/baktigunawan/ penerapan-teori-belajar-vygotsky-dalaminteraksi-belajar-mengajar. Diakses pada tanggal 16 Agustus 2016.

Hadi, S. (2005). Pendidikan matematika realistik dan implementasinya. Banjarmasin: Tulip

Hamiyah, N. \& Jauhar M. (2014). Strategi belajar mengajat di kelas. Jakarta: Prestasi Pustaka Publisher.

Mudhoffir. (1990). Teknologi instruksional: sebagai landasan perencanaan dan penyusunan program pengajaran. Bandung: Remadja Rosda Karya.

Uno, H. \& Nurudin, M. (2012) Belajar dengan pendekatan PAIKEM. Jakarta: Bumi Aksara

Kartodiwirio, S. K. \& Abadi, A. (2005). Album Bandoeng tempo doeloe. Bandung: Navpress Indonesia

Slavin, R. E. (2009). Educational psychology: theory and practice. Fifth Edition. Boston: Ailyn and Bacon Publishers

Soviawati, E. (2011). Pendekatan matematika realistik (PMR) untuk meningkatkan kemampuan berpikir siswa di tingkat sekolah dasar. Jurnal Pendidikan. Edisi Khusus No. 2, ISSN 1412$565 \mathrm{X}$.

Wijaya, A. (2012). Pendidikan matematika realistik (suatu alternatif pendekatan pembelajaran matematika). Yogyakarta: Graha Ilmu. 